\title{
Paradigmaváltás(ok) a magyarországi turisztikai desztinációk fejlesztésében és menedzselésében
}

\author{
Szerzók: Aubert Antal ${ }^{1}$ - Barcza Attilla² - Gonda Tibor ${ }^{3}$ - Horváth Zoltán ${ }^{4}$ - Pálfi Andrea ${ }^{5}$
}

Tanulmányunkban a hazai turizmus irányítás változó rendszerével foglalkozunk, amelynek elmúlt csaknem tíz évében desztinációs szinten tagadhatatlanul meghatározó szereplői voltak a turisztikai desztináció menedzsment (TDM) szervezetek. Munkánk során áttekintettük a TDM szervezetek létrehozására, müködésük finanszírozására kiírt pályázatokat, hiszen ezekbôl kirajzolódtak a hazai TDM rendszer sajátosságai. Egy kérdôíves felmérés keretein belül a TDM rendszer nehézségeire és a rendszerben rejlö veszélyekre kívánunk rávilágítani.

2016-ban, a Magyar Turisztikai Ügynökség megalakulásával új fejezete kezdődött a hazai turizmus tervezésnek és menedzselésnek, amelynek alapjait a Nemzeti Turizmusfejlesztési Stratégia 2030 c. dokumentum alapján tekintettünk át. A kijelölt kiemelt turisztikai fejlesztési térségek, mint új térkategóriák, meghatározó egységei lesznek az elkövetkezendó tervezési és megvalósítási időszaknak, amely alapjaiban határozza meg az egyes turisztikai célterületek jövójét. Tanulmányunk célja, hogy a témában átfogó képet nyújtsunk a turisztikai szektor gyakorlati és elméleti szakemberei számára az elmúlt időszakot áttekintve, illetve az elkövetkezendő időszak terveit vázolva, amelyek természetesen nemcsak a turizmus gazdaságra hatnak, hanem éppúgy meghatározóak a desztinációk területi megjelenése és tervezése nyomán, hovatovább a későbbi területi márkázás és márka identitás kialakításának vonatkozásában.

Kulcsszavak: TDM szervezetek, desztináció, desztináció menedzsment, kiemelt turisztikai fejlesztési térség.

\section{Bevezetés}

A turizmus, komplexitásánál fogva, egyértelmúen igényli a köz- és magánszféra együttmúködését mind a fenntarthatóság, mind a versenyképesség okán (TŐZSÉR 2010, SZIVA 2010, PAPP 2013). A turizmus külső- és belső rendszerjegyeinek harmonikus múködtetésére az egyes történelmi időszakok a turizmusirányítás- és menedzselés különböző formáit dolgozták ki, melyek több-kevesebb ideig megkísérelték e bonyolult rendszert a különbözó szinteken múködtetni. A rendszerváltás a korábbi egyoldalú vertikális függőségnek vetett véget, mely után közel egy évtizedre volt szükség ahhoz, hogy a turizmusban is állami-önkormányzati szinteken múködőképes szervezetek jelenjenek meg (MT Zrt., RIB-ek, RMI-k, Tourinform irodák). Ez volt az első paradigmaváltás!

A komolyabb állami szerepvállalás a turizmus tudatos fejlesztésére vonatkozóan a Széchenyi Terv I.-ben jelent meg először, amikor hazai forrásokból

\footnotetext{
egyetemi tanár, Pécsi Tudományegyetem, aubert@ttk.pte.hu 2 PhD-hallgató, Pécsi Tudományegyetem, barcza.attila@sopron.hu 3 egyetemi adjunktus, Pécsi Tudományegyetem, gonda.tibor@ktk.pte.hu ${ }^{4}$ PhD-hallgató, Pécsi Tudományegyetem, hozool@gmail.com ${ }^{5}$ tudományos segédmunkatárs, Pécsi Tudományegyetem, palfia@gamma.ttk.pte.hu
}

jelentôs termékfejlesztés valósult meg, az egészségturizmus kiemelt prioritásával. Az EU-források és irányelvek mentén az alulról szerveződés, a desztináció alapú fejlesztés és menedzselés jegyében a Nemzeti Turizmusfejlesztési Stratégia 20052013 (NTS 2005) fogalmazta meg először a TDM rendszer kiépítésének szükségességét. Ez volt a második paradigmaváltás!

Tanulmányunkban ennek pályázati szakaszait elemezzük részletesen, mely 2016-ig tart, amikor is sor került a turizmus irányításának újabb átszervezésére, az állami szerepvállalás hangsúlyos részvételével és egy új szereplő, a Magyar Turisztikai Ügynökség (MTÜ) megjelenésével. Ez a harmadik paradigmaváltás!

Röviden kitérünk a napjainkat is befolyásoló új fejlesztési stratégiára, melyet a Nemzeti Turizmusfejlesztési Stratégia 2030 (NTS 2030) (2017) dokumentum testesít meg.

\section{Módszertan}

A szekunder források, szakirodalmak megismerése mellett a publikáció egyik alapját a pályázati kiírások áttanulmányozása jelentette. A külföldi, németajkú országok mintája alapján bevezetett TDM rendszer hazai sajátosságai ugyanis a pályázati kiírások alapján rajzolódnak ki, amelyekból látszik, hogy a rendszer mely sarokkövei kerültek itthon adaptálásra, illetve milyen irányelvek voltak a meghatározók a rendszer 'fizikai' és elméleti kiépítése 
Lektorált tanulmányok

során. A pályázati kírások tartalomelemzése során az alábbi szempontok jelentették a vizsgálat prioritását: a támogatás célja, célrendszere; a támogatás mértéke és annak kritériuma (vendégéjszaka számok), valamint a támogatható tevékenységek köre.

Emellett az NTS 2030 (2017) stratégiai dokumentuma is alapjául szolgált jelen cikkünknek, hiszen ebből kitûnik a magyarországi turizmusirányításban zajló szemléletváltás új irányvonala.

A szekunder források mellett a tanulmány egy primer kutatás, egy online kérdőíves felmérés, eredményeire alapozva kívánja bemutatni a hazai TDM rendszer múködésének jellegzetességeit. A kérdőíves megkérdezésre 2016-ban került sor, amikor 81 szervezet számára került kiküldésre az a komplex kérdôív, amelyet 54 szervezet töltött ki. A kérdóív vizsgálta a TDM szervezetek humánerőforrás jellemzőit, valamint azok fejlesztésére tett gyakorlatait, a TDM szervezetek általános tevékenységét, termékfejlesztési és marketingkommunikációs gyakorlatait, illetve a rendszer nehézségeit és gyenge pontjait. Ez utóbbi részegység eredményeit mutatja be a tanulmány.

\section{Eredmények}

\subsection{TDM SZERVEZETEK KIÉPÍTÉSÉNEK TÖRTÉNETI SZAKASZAI ÉS FŐBB JELLEMZÖI}

A desztináció menedzsment rendszer gyökerei Nyugat-Európába vezethetők vissza. Német, osztrák, svájci gyakorlatok és szakirodalom mintájára került sor a hazai alapelvek kijelölésére és a rendszer bevezetésére (BIEGER 2005, ZEHRER et al. 2005, LUFT 2007). A különbözó szakirodalmak alapján elmondható, hogy a desztináció egy olyan komplex rendszer, amelyben a különbözó turisztikai vállalkozók és a turizmusban érintett szereplók egymással szoros kapcsolatban állnak, az együttmúködésben rejló elönyöket, szinergiákat felismerik, és azokat az "együttmüködve versenyezni" elv alapján igyekeznek kihasználni, a piacra vinni.

LENGYEL (2008) szerint a turizmus számára fontos kapcsolati rendszert a különböző környezeti szférák (természeti, politikai, gazdasági) összessége alapjaiban határozza meg, amelynek kooperálására, koordinálására az ún. desztináció menedzsment rendszer lehet megfelelő. BIEGER (2005) szerint a TDM rendszer lényege a célterületben gondolkodás, és az adott célterületen a turizmusban érintett politikai és privát szektor összefogása, a turisztikai tevékenység koordinálása, különösen a közös marketingtevékenység, a tervezés- és kínálatkoordináció.
A hazai TDM rendszer kiépítésének négy fontos alapelve volt (alulról építkezés, partnerség, szakszerúség, finanszírozás) (LENGYEL 2008). Az elsó és legfontosabb, hogy a TDM szervezeti rendszer kiépítése - az esetek nagy részében - alulról felfelé történt, a partnerség minél szélesebb körú kialakításával. E szempont érvényesülését az elôzetes, Nemzetgazdasági Minisztérium (NGM) által felügyelt regisztráció során fokozottan ellenőrizték. A participáció - azaz az érintettek tényleges bevonása - létfontosságú ugyanis a folyamatos együttmúködés és érdeklódés fenntartása érdekében. Ez a 2016-os kérdőíves felmérés alapján is jól látszik, hiszen ahol ez az elv sérült, a tényleges szakmai múködés is kevésbé zökkenőmentes. A sikeres desztináció menedzsment folyamatban a TDM szervezetek operatív módon töltenek be kezdeményező és koordináló szerepet, azonban a munkájuk csak akkor lehet hatékony, ha a különbözó érdekcsoportokat, érintetteket is aktívan be tudják vonni a tervezés első szakaszától, a döntési fázison át, a megvalósításig. Erre egyértelmú legitimitást nyújtott számukra az önkormányzattal megkötött feladatátadási szerződés, mely a pályázatok kötelezôen előírt feltétele volt. A tagok céljainak ismeretében, a szerződésnek megfelelóen a TDM szervezetek látják el a rendelkezésre álló erőforrások megfelelő felhasználását, gondoskodnak az együttmúködés ösztönzéséről, vagy akár az ehhez szükséges közvetítooi és kutatási feladatok ellátásáról (AUBERT - SZABÓ 2007).

A szervezetek munkájának mindennapi és stratégiai, hosszútávú koordinálásához elengedhetetlen a szakszerúség, a létrehozott turisztikai termékek és a kialakított partnerség megfeleló múködtetése, a desztináció keresleti és kínálati jellemzóinek, vagy akár a turisztikai trendek alakulásának ismerete.

A kialakult rendszer fenntartásához kiszámítható és biztos finanszírozási háttér szükséges, amelyet hazánkban 2016-ig leginkább a pályázati források biztosítottak. A szervezetek a vonatkozó pályázati forrásokból, valamint az önkormányzat által átadott idegenforgalmi adó hozzájárulásból, a tagdíj-hozzájárulásokból, illetve saját tevékenységból eredô bevételekből finanszírozták tevékenységüket, amelyhez egyesületi vagy non profit $\mathrm{kft}$. jogi háttérrel rendelkeztek.

Jelentôs elórelépés volt a TDM rendszerben, hogy a TDM szervezetek tevékenységükkel lehetốséget nyújtottak az addig csupán egy-egy vonzeróre, attrakcióra és nem a komplex turisztikai termékre koncentráló, egymástól függetlenül 
múködő, sokszor jellemzően csak a promócióban kicsúcsosodó vendégfogadói tevékenységek kiváltására, újragondolására, új szintre emelésére. Ezáltal lendületet kapott a turisztikai termékfejlesztés és a desztinációk turisztikai szereplőinek célterület alapú kooperációja. A közös kínálatfejlesztés alapjainak és hátterének megteremtésén túl hangsúlyos szerepet kapott továbbá a marketingkommunikáció, különösen az internet és a közösségi média, illetve olyan tevékenységek is egyre inkább megjelentek a desztinációk piacra vitele során, amelyek noha kevésbé hangsúlyos és meghatározó szerepet kapnak jelenleg - leginkább forrás- és kapacitáshiány miatt -, mégis elengedhetetlen feltételei a stratégiai és hosszú távú tervezésnek, menedzselésnek. Ilyen például a monitoring tevékenység, vagy akár a humánerőforrás képzés, fejlesztés, legyen szó akár a tagokról vagy a TDM szervezet munkatársairól (PÁLFI 2013, PÁLFI 2017).

A sikeres TDM tevékenység érdekében a szervezetek múködési területének lehatárolása különösen fontos feladat, mely során több szempontot kell figyelembe venni (például vendégéjszaka számok, történeti előzmények, természetföldrajzi és/vagy néprajzi határok, imázs) (AUBERT 2008, AUBERT 2009, SOMOSSY - LÔRINCZ 2014). Ez elsősorban a sikeres piaci pozícionálás, a márkaépítés és a célszegmensek meghatározása miatt szükséges, tehát a szervezeti múködés megkezdésének kiindulópontja, tulajdonképpen az egy desztinációban való gondolkodás alapja. Ugyanakkor fontos azt is látni, hogy a tervezés során nemcsak a desztináció határaival kell tisztában lenni, hanem a célterületet meghatározó turisztikai termékeket is ismerni kell, hiszen a különböző turisztikai termékek eltérő menedzsment feladatokat determinálnak (AUBERT et al. 2012, GONDA - SPIEGLER 2012, JÓNÁS-BERKI et al. 2015, PÁLFI et al. 2015, KÖBLI 2015, HORVÁTH et al. 2016).

\subsubsection{Elsố körös TDM pályázatok (2008-2010)}

Az első pályázati felhívásban (2008) kerültek rögzítésre a TDM szervezetek létesítésére vonatkozó alapelvárások, melyekben főként a szervezetek kialakítását és a vendégfogadási feltételek megteremtését túzték ki célul. Így például, hogy egy települési önkormányzat csak egy helyi TDM szervezetnek lehet teljes jogú tagja. A szervezetek együttmúködési megállapodást kötöttek az önkormányzattal, a szervezet kiszámítható múködésének biztosítása érdekében, a projekt megvalósítására és annak befejezésétől számított öt év időtartamra. A megállapodás ér- telmében az önkormányzat az állami hozzájárulással megnövelt, beszedett idegenforgalmi adó 20\%-át köteles a TDM munkaszervezete részére átadni, vagy a TDM munkaszervezet kötelezően előírt minimális éves szakmai, múködési forrásainak legalább 65\%-át biztosítani. A támogatás maximális mértéke az összes elszámolható költség arányában legfeljebb 85\% lehetett. A desztinációkat régiónként eltérő vendégéjszaka szám, valamint az ehhez kapcsolódó IFA alapján határolták le. A Balaton Kiemelt Üdülőkörzet területén magasabb követelményeket támasztott a pályázati kiírás, melyekhez ellenben magasabb támogatásokat társított. A Kiemelt Üdülőkörzet területén megkülönböztetett kiemelt turisztikai desztinációkat (150 ezer feletti vendégéjszaka) és turisztikai desztinációkat (80 ezernél magasabb vendégéjszaka). ${ }^{6}$ Ezzel szemben a tervezési-statisztikai régiók ROP-jai esetében megkülönböztetett desztinációs szintú helyi turisztikai együttmúködéseket is, ahol régiónként minimálisan 15-50 ezer vendégéjszaka számot állapított meg. ${ }^{7}$ A pályázati kiírások továbbá nyilatkoztak a szervezetek kialakításának összetételéről, az önkormányzatok, illetve vállalkozások hozzájárulásáról. Az elsô pályázati forduló szigorúbb volt, olyan jelentősebb desztinációk pályáztak, melyben a turizmusnak kialakult hagyományai voltak, erôs, jól meghatározható turisztikai termékkel rendelkeztek. A pályázat nagy hangsúlyt fektetett a turistafogadás körülményeinek megteremtésére, így a meglévő irodák korszerúsítésére, vagy akár például az adott desztinációban kialakított tematikus utak, városnéző séták kitáblázására. A pályázaton való részvétellel csak a Nemzetgazdasági Minisztérium által regisztrált szervezetek élhettek.

Noha a 2005-ös NTS elfogadása és a konkrét TDM fejlesztési pályázatok megjelenése (2008) között látszólag a szükségesnél több idő telt el, valójában sikeresnek mondható ez az időszak az alábbiak miatt:

- A ROP-ok prioritásai és konkrét pályázati célkitúzései közé bekerültek a TDM szervezetek megalakulását és múködését segítő pályázatok.

- Alulról szerveződve létrejöhettek és megerôsödhettek a helyi turisztikai egyesületek, illetve nonprofit kft-k.

- Megindulhatott a TDM szervezetek regisztrációjára való felkészülés, illetve megtörténtek az első regisztrációk.

\footnotetext{
${ }^{6}$ http://palyazat.gov.hu/doc/1567

${ }^{7} \mathrm{http}: / /$ palyazat.gov.hu/doc/1569
} 
Lektorált tanulmányok

\subsubsection{Második körös TDM pályázatok (2010-2015)}

A második felhívás 2011-ben került kiírásra az Új Széchenyi Tervben „Helyi és térségi turisztikai desztináció menedzsment szervezetek és turisztikai klaszterek létrehozása és fejlesztése" címmel. A pályázat alapvetó célja megegyezett a korábbi kiírásokkal, továbbra is elsődleges cél volt a TDM rendszer kialakítása és fejlesztése, de már a marketingtevékenységet is erôsíteni kívánták. A helyi és térségi szervezetekre vonatkozóan külön is összegyújtötte a támogatott célokat, azonos feladatkörökkel, de eltéró hangsúllyal. Térségi TDM szervezet létrehozásához minimum két regisztrált helyi TDM szervezet összefogását támogatta a kiírás, valamint a térségi desztináció területi kiterjedését minden esetben az adott terület komplex tájegységi kínálatának figyelembevételével ajánlotta meghatározni. ${ }^{8}$ A pályázási folyamatban továbbra is az NGM által regisztrált szervezetek vehettek részt, melyek egyesületként vagy non-profit $\mathrm{kft}$ ként múködtek. Nem támogatható kategóriába esett több olyan tevékenység, amelyeket korábban támogattak (például iroda kialakítása), tehát elsősorban a már meglévő szervezetek múködésének továbbfejlesztése volt a cél. A támogatás mértéke maradt az elszámolható költség maximum 85\%-a. A pályázatot 2011 szeptemberében felfüggesztették, majd 2012-ben a felhívás újból kiírásra került. Új elemként jelent meg a gyógyhelyi TDM-ek megkülönböztetése, melyek a térségi szervezetekhez hasonlóan maximum 100 millió forint támogatást nyerhettek. A döntés az egészségturizmus támogatására fókuszáló Új Széchenyi Terv Gyógyító Magyarország Ipari Programhoz köthetô, hátterében a korábbi ÚMFT prioritásainak átértékelése állt. A pályázati felhívásban a szükséges vendégéjszaka számokat csökkentették. A Balaton Kiemelt Üdülókörzet területén 50 ezerre, míg a tervezési-stratégiai régiókban 15-20 ezerre állították be a minimálisan teljesítendő vendégéjszaka számokat, amivel ugrásszerúen növelték a potenciálisan támogatható helyi szervezetek számát.

\subsubsection{Harmadik körös TDM pályázatok (2015-2016)}

Az NGM regisztráció során 2011 első félévében 56, míg második félévében 66 regisztrált TDM szervezetet tartottak számon. 2016-ban Magyarországon 86 regisztrált TDM szervezet volt, amelyek közül hét térségi szinten végezte tevékenységét (NGM 2016). Az ország egyes részein eltérô ütemben indult meg a TDM szervezeti struktúra kiépítése, régiónként jelentősek voltak a különbségek. Ennek

${ }^{8} \mathrm{http} / /$ palyazat.gov.hu/doc/3637 megfelelóen hazánk egyes turisztikai régiói TDM szervezetek által jól lefedettek (például Balaton, Észak-Magyarország), míg az ország más térségei (például Dél-Alföld) kevésbé.

Tevékenységük által a TDM szervezetek egyre jelentősebb szerepet töltöttek be az egyes desztinációk piacra vitelében, a partnerség kialakításában, a termékfejlesztésben és a marketingkommunikációban (PÁLFI 2017). Jelentőségüket mutatja, hogy az ország összes múködő szálláshely egységének mintegy 56,7\%-a, míg a szállásférőhelyek 50,1\%-a olyan desztinációkban került regisztrálásra, ahol múködött TDM szervezet. A vendégforgalom tekintetében is hasonló a helyzet, a vendégforgalom 42,7\%-a, míg a vendégéjszakák 46\%-a a TDM szervezettel rendelkező desztinációkban realizálódott (KSH 2016).

Noha a helyi szintú TDM szervezetek dominanciája jellemezte a hazai TDM rendszer kiépítését, mégis elmondható, hogy sok célterületen aktív desztináció fejlesztési munka indult el az országban (HANUSZ 2011, AUBERT et al. 2015, PÁLFI 2017). A TDM tevékenység minden desztinációban nagy hangsúlyt fektetett a termékfejlesztésre és a marketingkommunikációra, amelynek innovációi (például mobilapplikációk, turisztikai kártyák) széles körben terjedtek el az érintett területeken (PÁLFI 2016). Ezt erősítette a Magyar TDM Szövetség (MTDMSz) szakmai tevékenysége is, amelynek része volt az évente kétszer megrendezésre kerüló TDM konferenciák sorozata, melyen a szakma aktívan részt vett. Az ott bemutatott hazai és meghívott külföldi elóadók által prezentált jó gyakorlatok sok desztinációt inspiráltak, amelynek hatására a vendégfogadás feltételei (információnyújtás minősége és elérhetősége, garantált programok, kényelmi tényezók (például pihenópadok), turisztikai információs irodák megújulása) érezhetôen javultak.

Az új tervezési ciklusban (2014-2020) a pályázati rendszer megújítására került sor, amelyben már nem a régiós megközelítés kapta a főszerepet, így a 2015-ben megjelent TDM pályázatok a Gazdaságfejlesztési és Innovációs Operatív Program (GINOP) keretein belül kerültek kiírásra, összesen 2 milliárd forint nagyságú támogatási keretösszeggel. ${ }^{9} \mathrm{Az}$ új pályázati kiírást vizsgálva látható, hogy a cél elsősorban a már meglévő szervezetek támogatása, munkájának erősítése, valamint a térségi szint kiépítésének előmozdítása volt. Ennek megfelelően a 2011-2012-es pályázatokhoz képest a megemelt (de az első kiírásnál még mindig alacsonyabb) vendégéjszaka számok egyes célterületeket egyértelmúen kizártak a pályázók köréből. 2016 decemberében, a Magyar TDM Szövetség éves rendezvényén azon-

\footnotetext{
${ }^{9}$ https://www.palyazat.gov.hu/node/56703
} 
A 2009-2015 között kiírt TDM pályázatok fó jellemzői. Forrás: TDM pályázatok (2009, 2011, 2015)

\begin{tabular}{|c|c|c|c|c|}
\hline $\begin{array}{c}\text { TDM } \\
\text { pályázatok }\end{array}$ & $\begin{array}{l}\text { I. Első kör (Balaton) } \\
\text { (ROP) (2009) }\end{array}$ & $\begin{array}{l}\text { I. Elsố kör (Egyéb } \\
\text { régiók például Dél- } \\
\text { Dunántúl) (ROP) }\end{array}$ & $\begin{array}{l}\text { II. Második kör (ROP) } \\
\text { (2011 majd 2012) }\end{array}$ & $\begin{array}{l}\text { III. Harmadik kör } \\
\text { (GINOP) (2015-2016) }\end{array}$ \\
\hline $\begin{array}{c}\text { Pályázati } \\
\text { keretösszeg }\end{array}$ & \multicolumn{2}{|c|}{ 3,8 milliárd Ft } & $\begin{array}{c}\text { 5,4 majd } \\
\text { 2,14 milliárd Ft }\end{array}$ & 2 milliárd Ft \\
\hline 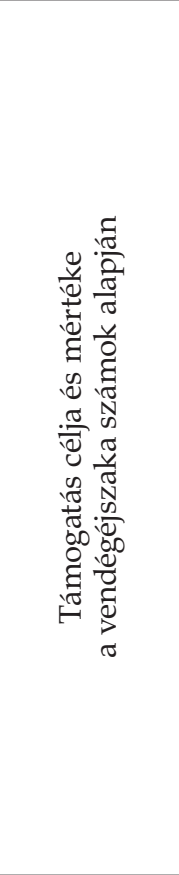 & $\begin{array}{l}\text { Helyi szintú } \\
\text { desztináció } \\
\text { menedzsment } \\
\text { szervezetek } \\
\text { kialakítása } \\
\\
\text { „Kiemelt Turisztikai } \\
\text { Desztinációk” } \\
\text { (150 ezer VÉJ feletti): } \\
50-60 \text { millió Ft } \\
\\
\text { „Turisztikai } \\
\text { Desztinációk” } \\
\text { (80 - 150 ezer VÉJ) } \\
\text { 25-50 millió Ft }\end{array}$ & $\begin{array}{l}\begin{array}{l}\text { Helyi szintú } \\
\text { desztináció } \\
\text { menedzsment } \\
\text { szervezetek } \\
\text { megalakítása }\end{array} \\
\text { „Kiemelt Turisztikai } \\
\text { Desztinációk" } \\
\text { (150 ezer VÉJ feletti): } \\
40-50 \text { millió Ft } \\
\\
\text { „Turisztikai } \\
\text { Desztinációk" } \\
\text { (50 - 150 ezer VÉJ): 30- } \\
42 \text { millió Ft } \\
\text { "Desztinációs szintú } \\
\text { helyi turisztikai } \\
\text { együttmúködések } \\
\text { támogatása” } \\
\text { (50 ezer VÉJ alatti): } \\
\text { 25-35 millió Ft }\end{array}$ & $\begin{array}{l}\text { Helyi, térségi } \\
\text { TDM szervezetek, } \\
\text { klaszterek kialakítása } \\
\text { és fejlesztése } \\
\text { Helyi TDM szervezet } \\
\text { esetén: } 20-50 \text { millió Ft } \\
\text { Gyógyhelyi TDM } \\
\text { szervezet esetén: } \\
20-100 \text { millió Ft } \\
\text { Térségi TDM } \\
\text { szervezet } \\
\text { esetén: 50-100 millió Ft } \\
\text { Minimális VÉJ } \\
\text { régiónként: Balatoni } \\
\text { Kiemelt Üdülőkörzet } \\
\text { területén } 50 \text { ezer; } \\
\text { Dél-Alföld } 17 \text { ezer, } \\
\text { Dél-Dunántúl 15 ezer, } \\
\text { Észak-Alföld } 20 \text { ezer, } \\
\text { Észak-Magyarország } 15 \\
\text { ezer, Közép-Dunántúl } \\
\text { 15 ezer, Nyugat- } \\
\text { Dunántúl } 20 \text { ezer }\end{array}$ & $\begin{array}{l}\text { Helyi és kiemelt } \\
\text { jelentőségú helyi, } \\
\text { valamint térségi } \\
\text { TDM szervezetek } \\
\text { támogatása } \\
\text { Helyi TDMszervezet } \\
\text { (min. } 30 \text { ezer VÉJ) } \\
\text { 10-20 millió Ft } \\
\text { Kiemelt jelentôségú } \\
\text { helyi TDM és térségi } \\
\text { TDM szervezet } \\
\text { (gyógyhely vagy } \\
\text { megyei jogú város, } \\
\text { legalább 200 ezer VÉJ, } \\
\text { vagy } 500 \text { ezer VÉJ) 30- } \\
\text { 65 millió Ft } \\
\text { A támogatási kérelem } \\
\text { beadását megelózó } \\
\text { egy éven belül } \\
\text { regisztrált helyi } \\
\text { TDM szervezettel } \\
\text { megalakuló vagy } \\
\text { bóvüló térségi TDM: } \\
\text { 30-85 millió Ft. }\end{array}$ \\
\hline 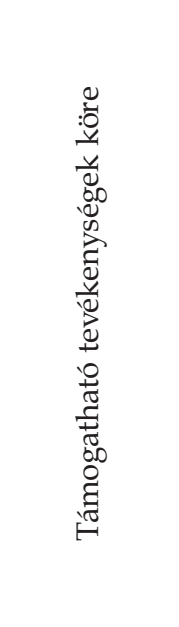 & $\begin{array}{l}\text { TDM szervezet- és há } \\
\text { beleértve a hálózatfejl } \\
\text { program elkészítését } \\
\text { TDM szakmai, szolgá } \\
\text { kínálatfejlesztési proj } \\
\text { beleértve a szolgáltatá } \\
\text { terv elkészítését } \\
\text { Helyi TDM szervezet } \\
\text { fejlesztése és eszközb } \\
\text { TDM e-turisztikai fej } \\
\text { eszközbeszerzés (kivé } \\
\text { Desztinációs szintú m } \\
\text { értékesítés-ösztönzési } \\
\text { fejlesztések, projektel }\end{array}$ & $\begin{array}{l}\text { atfejlesztés - } \\
\text { tési és partnerségi } \\
\text { tás- és } \\
\text { tek megvalósítása - } \\
\text { ejlesztési cselekvési } \\
\text { frastruktúra- } \\
\text { erzés támogatása } \\
\text { ztések: informatikai } \\
\text { TDM szoftver) } \\
\text { keting, PR, } \\
\text { kommunikációs } \\
\text { legvalósítása }\end{array}$ & $\begin{array}{l}\text { Helyi és térségi } \\
\text { szinten ugyanaz, } \\
\text { de eltéró hangsúllyal } \\
\text { Termékfejlesztés/ } \\
\text { projekt-menedzsment; } \\
\text { Turisztikai infor- } \\
\text { mációs rendszerek } \\
\text { múködtetése; } \\
\text { Folyamatos kapcso- } \\
\text { lattartás /együttmú- } \\
\text { ködés; } \\
\text { Marketing tevékeny- } \\
\text { ség; Szemléletformá- } \\
\text { lás, oktatás és képzés; } \\
\text { Monitoring; Infra- } \\
\text { struktúrafejlesztés és } \\
\text { eszközbeszerzés }\end{array}$ & $\begin{array}{l}\text { Helyi: } \\
\text { Termékfejlesztés; } \\
\text { Szemléletformálás, } \\
\text { oktatás és képzés; } \\
\text { Marketing } \\
\text { tevékenység; } \\
\text { Monitoring } \\
\\
\text { Térségi: } \\
\text { Termékfejlesztés } \\
\text { Marketing } \\
\text { tevékenység } \\
\text { Szemléletformálás, } \\
\text { oktatás és képzés } \\
\text { Monitoring }\end{array}$ \\
\hline
\end{tabular}

Forrás: AUBERT et al. 2016

ban bejelentésre került, hogy várható a pályázati felhívás visszavonása, amelyre a hónap végén jogszabályi keretek között került sor.

Az eddigi TDM pályázatok azonosságait és különbözőségeit az 1. táblázat foglalja össze.

\subsection{PROBLÉMÁK ÉS VESZÉLYEK A HAZAI TDM SZERVEZETEK MÜKÖDÉSÉBEN}

LENGYEL M. (2008) már a TDM szervezeti rendszer bevezetésének elején összegezte a szervezetek 
Lektorált tanulmányok

gyakorlati múködése során problémát jelentô kihívásokat, melyek elsősorban azok fenntarthatóságára, múködésére alapvetően hatással vannak, és amelyekkel mi is egyetértünk. Így például:

- Az önkormányzat és a magánszektor közötti feladatmegosztás a felek közötti bizalom hiányában formális marad, ezáltal a források biztosításában és felhasználásában nehézkes az egyetértés.

- Az egyes szintek között a feladatellátás nem különül el, minden szinten hangsúlyosan kívánnak foglalkozni a marketing minden elemével.

- Az önkormányzati finanszírozás mértéke (az IFA alacsony visszaforgatása a turizmusba) alacsony és bizonytalanság jellemzi.

- A rendszer múködése túlzott mértékben támaszkodik a pályázatokra és az általuk elérhető aktuális forrásokra.

- A szervezetek elfogadottsága, szakmai tudásuk megkérdőjelezése a helyi szereplók körében.

Saját kutatásaink és ezt kiegészítve a 2016-os online kérdőíves kutatásunk további gyengeségekre és veszélyekre hívta fel a figyelmet, rámutatva ezzel a TDM szervezeti rendszer múködésének alapvetó nehézségeire Magyarországon (PÁLFI 2017).

- A kérdő́ivben megadott válaszok alapján, a TDM szervezetek megítélése szerint, múködés szempontjából az utazási szokások megváltozása számít legkevésbé veszélyt okozó tényezónek. Ez arra utal, hogy a szervezetek vagy egyértelmú célszegmensekkel rendelkeznek, vagy nyitottak és készek a felmerüló változások trendekhez igazodó lereagálására. Szintén kevésbé jelentős veszélyfaktornak ítélték meg a desztináció fô turisztikai termékének, attrakciójának versenyképességi csökkenését, ami arra utal, hogy a válaszoló TDM szervezetek többsége stabilnak érzi fó turisztikai termékét, attrakcióját.

- A desztináció határain túlmutató együttmúködések hiányosságait, csak a szervezetek 13\%-a ítéli meg múkködést befolyásoló nehézségként, ami arra utal, hogy sokkal inkább a belsó kapcsolatokra és azok alakulására alapozzák a TDM tevékenységet.

- A szervezetek 16,7-16,7\%-a úgy gondolja, hogy a tagok közötti érdekellentétek és az országos, szakmai és civil szervezetekkel való együttmúködések hiánya veszélytényezô a múködés során.

- A rendszer kialakítása elején, az alulról építkezés elvének betartása érdekében, az önkormányzatok döntési súlyának optimalizált módját túzték ki célul. Hivatalosan, az önkormányzatok ereje a döntéshozatalban nem lehet meghatározó, ugyanakkor köztudott, hogy vannak olyan TDM szervezetek, ahol a múködést az önkormányzat dominanciája hatja át. Szerencsére azonban nem ez, inkább a kompromisszumos megoldások jellemzik a rendszer múködését. A válaszoló szervezetek $22,2 \%$-a szerint azonban veszélyezteti $a$ túlzott önkormányzati befolyás a múködést, míg 27,8\%uk szerint az "alulról építkezés" elvének sérülése jelenthet problémát.

- A szervezetek 22,2\%-ának múködése szempontjából nehézséget jelent, hogy a múködés során a rövid távú sikerek elérése dominál, amely leginkább a pályázati ciklusokban való gondolkodás rendszerére vezethető vissza. Ez azonban nélkülözi a hosszú távú, stratégiai tervezés módszerének alkalmazását.

- A TDM szervezetek 29,6\%-a gondolja úgy, hogy az irányítási rendszerben jelenleg is meglévô tisztázatlan kérdések (például a TOURINFORM irodák kérdésköre vagy az utazási irodai tevékenység) zavart okoznak a menedzsment múködése során.

- Ugyanilyen arányban viszont azt sem tartják szerencsésnek a szervezetek, hogy a pályázatok alapján a desztinációk lehatárolása inkább mennyiségi (például vendégéjszakák száma), mintsem egyéb elvek mentén (például geográfiai vagy termék alapon) történt.

- Erdekes, hogy az egyes együttmúködésekre vonatkozó válaszlehetôségek ugyanolyan arányban, 33,3-33,3\%, számítanak veszélytényezőnek a múködés során a TDM szervezetek válaszai alapján. Így az együttmúködések hiánya a tagok és a TDM szervezetek között, az együttmúködések hiánya a tagok között, valamint az együttmúködések hiánya a térségben, a térségi szint kiépitetlensége valós veszélyei a hazai TDM rendszernek, noha a partnerség kialakítása szintén a TDM szervezetek létrehozásának és múködésének egyik feltétele, indikátora.

- A TDM szervezetek 35,2\%-a a TDM szervezetek turizmus irányítási rendszerben megfigyelhető útkeresését jelölte meg múködési nehézségként. A megalakulás óta a TDM szervezetek irányítási rendszerben betöltött helye és szerepe nem tisztázódott, mára további, államilag (nemcsak anyagi, hanem elvi szinten) támogatott és elismert tevékenységük is kérdésessé vált annak ellenére, hogy noha vannak szervezetek, amelyek létrehozásában csak a pályázati pénzek lehívása játszott szerepet, maga a múködési forma sikeressége megkérdőjelezhetetlen a sikeres példák alapján. 
-38,9\%-a a szervezeteknek úgy véli, hogy a pályázatok kötöttsége és a felhasználási feltételek szabályozottsága, korlátozottsága komoly akadályozó tényezô a professzionális munka során. A vendégéjszaka szám alapú lehatárolás és a pályázati tevékenységi körök túlzott szabályozottsága mellôzi az egyes desztinációk specifikus jegyeinek figyelembe vételét. Noha mindezek fontosak az egységes múködés keretfeltételeinek kialakítása érdekében, ez mégis nehézségeket és sablonmegoldásokat szül (például honlapok hasonló elvú kialakítása, egyéb gyakorlatok átgondolatlan elterjedése).

- Az egységes múködési környezet kialakítását a turizmus törvény segíthetné, hiszen az nemcsak a TDM szervezetek, hanem az egész turizmus ágazat múködését szabályozná és keretbe foglalná. Ez azonban a mai napig nem került kialakításra, melynek hiányát a szervezetek 48,1\%-a komoly, múködést gátló tényezônek véli.

- A TDM szervezetek 49,3\%-a szerint a múködést akadályozza, hogy a turisztikai szereplók (vállalkozók, attrakciók üzemeltetôi) a mai napig sem ismerik és/vagy megkérdôjelezik a TDM szervezetek tevékenységét, a sikeres példák ellenére is. Amellett, hogy ez tükrözi a magyar hozzáállást a témához, egyben utal arra is, hogy a TDM szervezetek lobbi tevékenysége gyenge és hiányzik az állami, szakmai megerósítés a TDM szervezetek felé.

- Nem meglepó módon a finanszírozási nehézségek $(79,6 \%)$ jelentik a legnagyobb veszélyt a TDM szervezetek múködése során a kitöltók szerint, amelynek pályázatoktól való függósége (57,4\%) is a múködést befolyásoló nehézségek egy dimenziója. Egy rendszer akkor nevezhetó jól múködőnek, ha külső források nélkül, önfenntartóan tud múködni, ehhez azonban elengedhetetlen a támogató társadalmi-gazdasági-politikai környezet. A költségvetési kérdésekre így választ jelenthet a finanszírozási struktúra újragondolása, és akár új források bevonása (például idegenforgalmi hozzájárulás jelentôsebb attrakciót múködtetők részéről), melynek kidolgozása azonban optimálisan csak szabályozott keretek között történhet azért, hogy az egyes érintettek érdekei ne sérüljenek.

\section{3. ÚJ FEJLESZTÉSI SZEMLÉLET A TURIZMUSBAN}

A Magyar Turizmus Zrt. nevének Magyar Turisztikai Ügynökségre történő megváltoztatására, feladatköreinek és szervezeti felépítésének újraszer- vezésére 2016-tól került sor, amelynek nyomán körvonalazódni látszik - ezt az NTS 2030 meg is erősíti -, hogy a turizmus fejlesztése az elkövetkezendô idôszakban a korábbiaknál hangsúlyosabban és szervezettebben kap szerepet. Az NTS 2005-2013 céljainak egy része tovább él ugyan, alapvetôen eltér viszont a turisztikai tervezés korábbi alapegységének számító kilenc turisztikai régió vonatkozásában, hiszen megjelent a ",kiemelt turisztikai fejlesztési térségek" nevú "térkategória", valamint ezzel együtt a turizmus koncentrált fejlesztésének a stratégiája, amely magába foglalja a desztinációs alapú termék- és attrakciófejlesztést, a kapcsolódó „alapinfrastruktúra” ${ }^{\prime 10}$ fejlesztéssel és marketingkommunikációval együtt.

Ha az elmúlt csaknem tíz év desztináció tervezési alapegységeit egymásra vetítjük a kijelölt kiemelt turisztikai fejlesztési térségek területével, szembetúnő, hogy a magas vendégéjszakát realizáló TDM szervezettel rendelkezô desztinációk múködési területe fedi az újonnan kijelölt kiemelt turisztikai fejlesztési térségeket, ugyanakkor az ország egyes régióiban és területein a kiemelt turisztikai fejlesztési térségek nevesítése még várat magára (1. ábra).

Itt jegyeznénk meg, hogy a szakirodalomban is problémás a desztinációk lehatárolásának kérdésköre, számos megközelítés él (BIEGER 2005, AUBERT 2008, STEINECKE 2013), amelyek menynyiségi (például vendégéjszaka szám) és/vagy minőségi (például történelmi, néprajzi identitás) alapon húzzák meg a desztinációk határait a földrajzi térben. Ennek jelentősége hosszú távon mindenképpen fontos. Fóként a desztinációk márkázása, a márkadesztinációk és a desztinációs márkák kialakítása során lehet meghatározó fontosságú ez, hiszen napjaink turisztikai piacán az egyértelmúen beazonosítható, ugyanakkor egyedi termékjegyekkel rendelkező, minőségi szolgáltatást és élményt nyújtó desztinációk versenyképesek (SZABÓ 2006).

Röviden szeretnénk kitérni a desztináció alapú turizmusfejlesztés területfejlesztési összefüggéseire is annyiban, hogy elméletileg ismét felvetődik a turisztikai szektor megítélése e tekintetben. Az NTS 2030 ebból a szempontból első megközelítésben nem tér el elódjétól, az NTS 2005-2013tól, illeszkedési célrendszere a Nemzeti Fejlesztés 2030-hoz (Országos Fejlesztési és Területfejlesztési Koncepció) mind az átfogó fejlesztési célok, mind a specifikus szakpolitikai- és területi specifikus célok tekintetében közel azonos.

\footnotetext{
${ }^{10} \mathrm{Az}$ „alapinfrastruktúra” értelmezése az NTS 2030 szerint közlekedés, szálláshelyek, vendéglátóhelyek, míg a hazai turisztikai szakmai felosztás árnyaltabban fogalmaz: alapinfrastruktúra, turisztikai infrastruktúra, turisztikai szuprastruktúra (MICHALKÓ 2012).
} 


\section{TDM szervezetek múködési területe és a kiemelt turisztikai fejlesztési térségek} Magyarországon (2017)

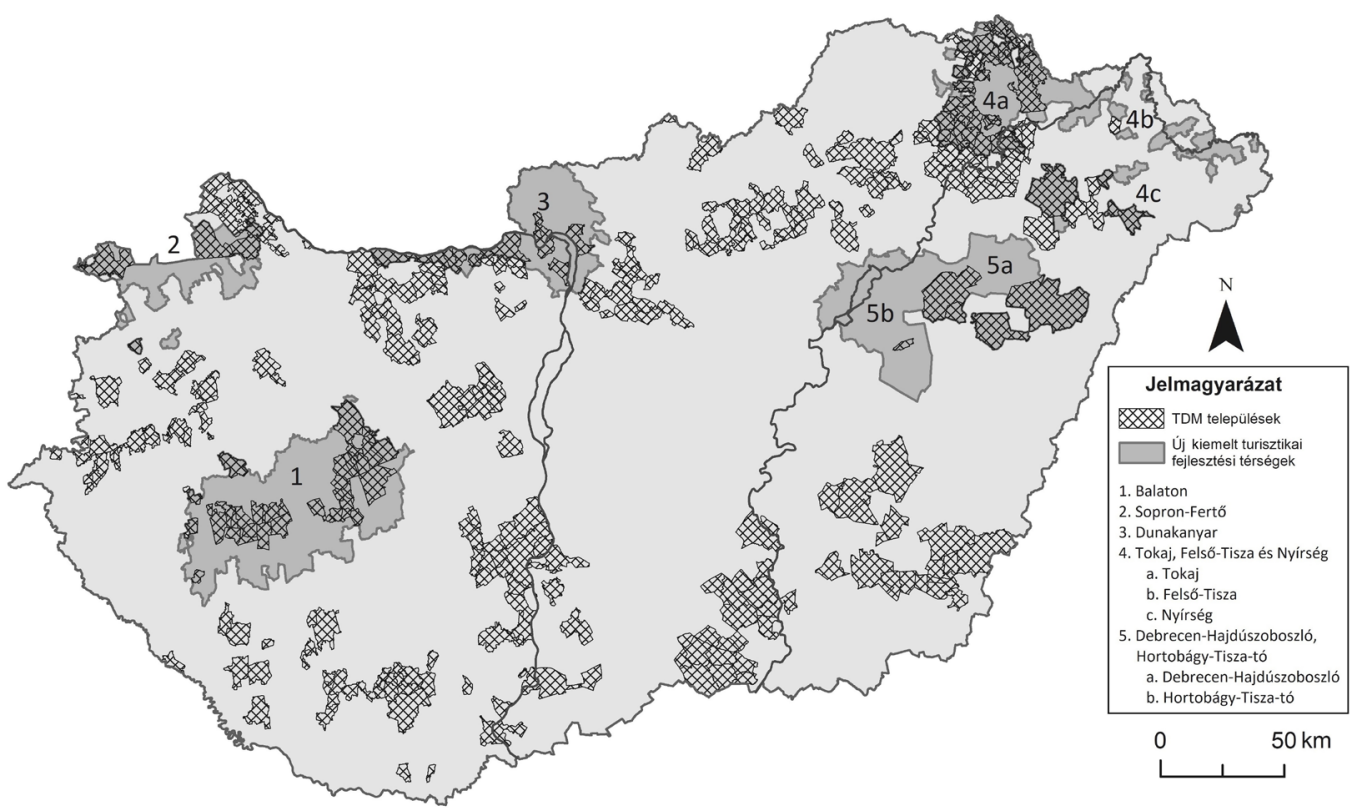

Forrás: NGM (2016) és a vonatkozó kormányhatározatok alapján saját szerkesztés ${ }^{11}$

A turizmus interszektorális mivoltából kiindulva, elismert multiplikátor hatását (lásd a GDP-hez való közvetlen és közvetett hozzájárulás mértékének különbségét) figyelembe véve kétségtelen ez az összefüggés, ugyanakkor a mélyebb szakmai összefüggések arra is felhívják a figyelmünket, hogy a turizmus nemcsak a területi különbségek mérséklésének eszköze, hanem diffúz vonzeróbázisa következtében a területi polarizáció eszköze is egyben (AUBERT 2001).

Ha az előző fejlesztési ciklus (2007-2013) turizmusfejlesztési hátterének területfejlesztési összefüggéseit keressük, akkor elmondhatjuk, hogy a régiós operatív programok desztináció menedzsment pályázatai az alulról szerveződés, a partner-

\footnotetext{
${ }^{11}$ 1092/2017. (II. 21.) Korm. határozat a Tokaj, Felső-Tisza és Nyírség kiemelt turisztikai fejlesztési térség meghatározásáról és a térségben meg valósítandó egyes fejlesztések megvalósításához szükséges források biztosításáról

1522/2017. (VIII. 14.) Korm. határozat a Debrecen, Hajdúszoboszló, Hortobágy és Tisza-tó kiemelt turisztikai fejlesztési térség meghatározásáról és a térségben megvalósítandó egyes beruházásokról

1550/2017. (VIII. 18.) Korm. határozat a Dunakanyar kiemelt turisztika fejlesztési térség meghatározásáról, valamint a térségben megvalósítandó egyes fejlesztésekről

1861/2016. (XII. 27.) Korm. határozat a Balaton kiemelt turisztikai fejlesztési térség meghatározásáról és a térségben megvalósítandó egyes fejlesztések megvalósításához szükséges források biztosításáról 1862/2016. (XII. 27.) Korm. határozat a Sopron-Fertő kiemelt turisztikai fejlesztési térség meghatározásáról és a térségben megvalósítandó egyes fejlesztések megvalósításához szükséges források biztosításáról
}

ség alapelvei mentén a belső erőforrások aktivizálására épültek, melynek hátterében az endogén erőforrások (BRUGGES 1981) modelljét véljük megtalálni. Kiinduló feltételezés lehet az „egyes településekben, térségekben található földrajzi, környezeti, történelmi, kulturális, társadalmi, gazdasági tényezők együttes rendszerének értelmezése és az ezen értéktartományok aktivizációját befolyásoló tényezők" (RECHNITZER 1990, RECHNITZER 1993), melyre a turisztikai termékfejlesztés komplexitása önmagában is példaként szolgálhat.

Az NTS 2030 koncentrált kiemelt turisztikai fejlesztési térségei (benne egyes desztinációk attrakció és szálláshely fejlesztési projektjeivel) elméleti háttere párhuzamba állítható a regionális gazdasági növekedés elméleteivel, kísérteties a hasonlóság a növekedési póluselmélettel (BOUDVILLE 1966), melynek gyakorlati példái a világ számos országában, Európában és Magyarországon (regionális pólusvárosaink, Modern Városok Program) is fellelhetôek. E szerint az ágazati polarizáció regionális polarizációt eredményez. Különösen igaz lehet ez a turizmus hazánkra jellemző területi koncentráltságát tekintve. Ezen a helyzeten az előző fejlesztési ciklus (2007-2013) sem változtatott lényegesen, a ROP-ok térben elszórt turisztikai projektjei nem hoztak áttörést. A turisztikai régiók közötti keresleti mutatók kisebb átrendeződés mellett ugyan, de továbbra 
A fejlesztési források (Mrd forint) és

\section{a szervezeti háttér alakulása (2016-2030)}

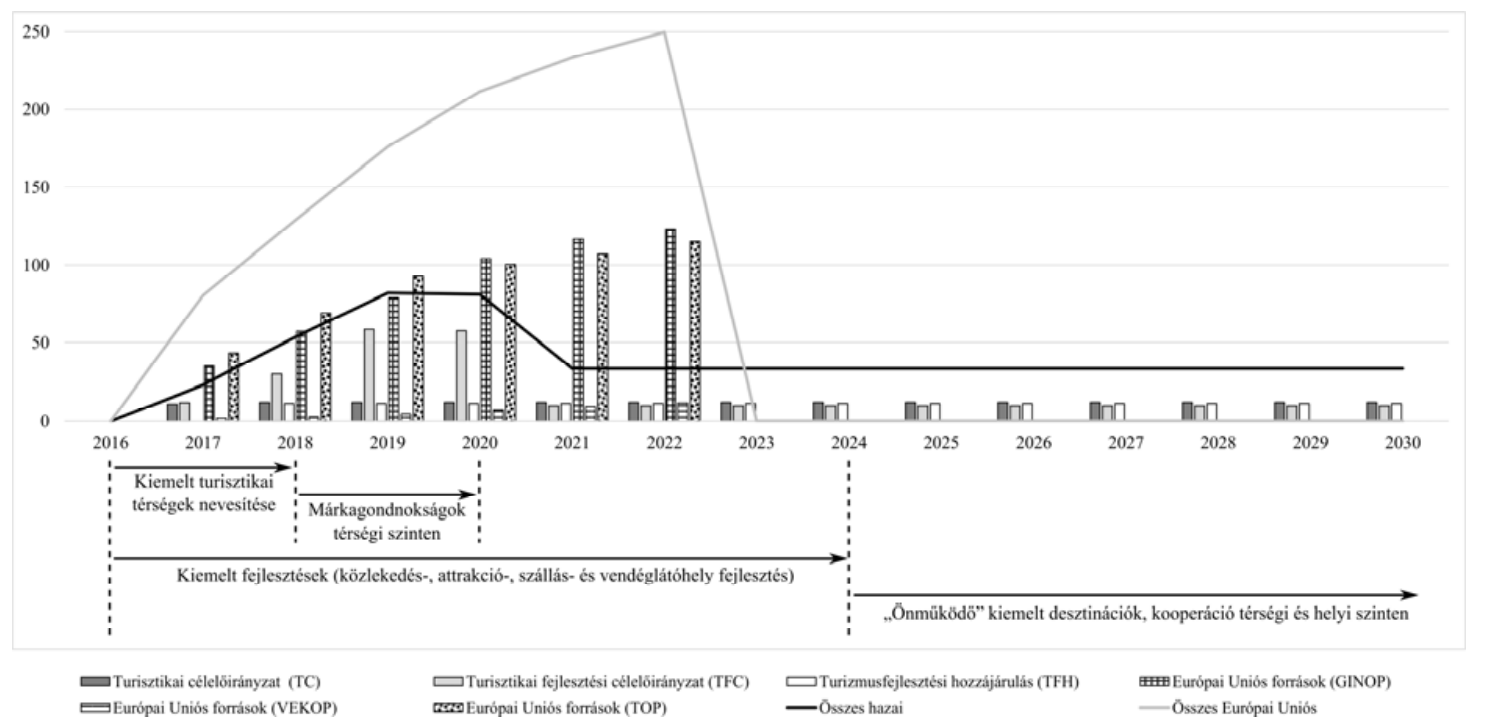

Forrás: NTS 2030 alapján saját szerkesztés

Megjegyzés: az Európai Uniós források a 2020 utáni időszakra még nem tervezhetők

is a klasszikus desztinációk (Budapest, Balaton, fürdővárosok) uralmát mutatják (AUBERT et al. 2013).

A 2. ábra jól szemlélteti e fenti területfejlesztési elméletek lekövetését a turizmusfejlesztésés menedzselés mentén. A tervezett stratégiai célok, a pénzügyi források az időszak első felében az állami szerepvállalás dominanciájára épülnek, míg a helyi és térségi szereplók aktivizálása, a kooperáció erősítése a fejlesztési ciklus második felére esik. A turizmusfejlesztés logikája viszont felveti e kettősség párhuzamos jelenlétének szükségességét, mind a hatékonyság, mind a helyi-térségi szereplók aktivizálása szempontjából nézve. Az ellentmondás feloldása szemléleti kérdés, a szakmai-szervezeti háttér rendelkezésre áll, a kooperáció szükségessége nyilvánvaló mind szakmai, mind fejlesztéspolitikai szempontból.

Ha a kiemelt turisztikai térségek jelentôs külső (hazai és EU) erőforrások eredményeként módosítani tudják turizmusunk területi struktúráját, a stratégia elérheti célját, melynek eredményeként a közvetlen turisztikai indikátorok teljesülése mellett a szektor diffúz hatásaként a területi polarizáció egy sajátos képe bontakozhat ki, melynek a hátterében a jövő „iparága”, a turizmus áll.

\section{4. Összegzés}

Tanulmányunk TDM elméleti/szakirodalmi összefoglalóján túl részletesen elemzi a TDM pályázatok kiúrásának körülményeit és azok EU-pályázati rendszerhez való illeszkedését. Turizmus törvény hiányában a turizmusirányítás- és menedzselés formáit (egyesület, $\mathrm{kft}$.) tulajdonképpen a pályázati felhívás keretei szabták meg, a vendégéjszaka számmal pedig (régiónként eltérô) a koncentráció elvét igyekeztek teljesíteni. A TDM pályázatok mellett a hálózatosodást elôsegítendően a turisztikai klaszterek is megjelentek, melyek térbeli jellemzői eltérnek a TDM szervezetek földrajzilag kompakt tömbjétől. A vendégéjszaka alapú lehatárolás ugyanakkor sokszor ellentmondásba került a térségi kohézió földrajzi-, történelmi- és néprajzi alapjaival.

E korszak kritikáját adja a „Problémák és veszélyek a hazai TDM szervezetek múködésében" címú fejezet, ahol felmérésünk szerint felszínre kerültek azok a finanszírozási és szemléleti problémák és nehézségek, amelyek akár el is lehetetleníthetik e szervezetek hosszú távú múködését.

A 2016. év az új fejlesztési szemlélet megjelenésének az éve, egy erőteljes állami szerepvállalással. Az NTS 2030 (2017) dokumentum rögzíti ennek a szemléletnek a fejlesztési és menedzselési forrásait és szervezeteit, stratégiai lépéseit. 
A tanulmány röviden foglalkozik a turizmusfejlesztés területfejlesztési összefüggéseivel is, mely alapján arra a következtetésre juthatunk, hogy az EU-alapelvek mentén, a hatékonyság szemszögét is figyelembe véve szerencsés lenne a jövőt illetóen mindkét modellt alkalmazni, értelmezni és kivetíteni a turisztikai szektorra.

\section{Köszönetnyilvánítás}

Jelen publikáció/kutatás az Európai Unió, Magyarország és az Európai Szociális Alap társfinanszírozása által biztosított forrásból az EFOP-3.6.2-162017-00017 azonosítójú „Fenntartható, intelligens és befogadó regionális és városi modellek" címú projekt keretében jött létre.

\section{Felhasznált irodalom}

AUBERT A. - GONDA T. - HORVÁTH Z. PÁLFI A. (2016): TDM szervezetek Magyarországon: múlt, jelen, jövő. In: Hanusz Á. (szerk.): Turisztikai jövókép Szabolcs-Szatmár-Bereg Megyében. Szabolcs-Szatmár-Bereg Megyei Területfejlesztési és Környezetgazdálkodási Ügynökség, Nyíregyháza. pp. 77-90.

AUBERT A. - JÓNÁS-BERKI M. - PÁLFI A. (2015): A desztináció megújulás kérdései Magyarországon. In: Rátz T. - Michalkó G. (szerk.): Kreativitás és innováció a turizmusban. Kodolányi János Főiskola; MTA CSFK Földrajztudományi Intézet; Magyar Földrajzi Társaság, Székesfehérvár; Budapest. pp. 223-232.

AUBERT A. - JÓNÁS-BERKI M. - MARTON G. - PÁLFI A. (2013): Magyarország turizmusa a kelet-közép-európai térségben. In: Frisnyák S. - Gál A. (szerk.): Kárpát-medence: természet, társadalom, gazdaság. Nyíregyházi Főiskola Turizmus és Földrajztudományi Intézet; Bocskai István Gimnázium, Nyíregyháza, Szerencs. pp. 447-462.

AUBERT A. - JÓNÁS-BERKI M. - MARTON G. - PÁLFI A. (2012): A rurális terek TDM szervezeteinek jellemzői Magyarországon. In: Hanusz Á. (szerk.): A turizmus területi dimenziói. Nyíregyházi Főiskola Természettudományi és Informatikai Kar Turizmus és Földrajztudományi Intézete, Nyíregyháza. pp. 19-28.

AUBERT A. - CSAPÓ J. - PIRKHOFFER E. PUCZKÓ L. - SZABÓ G. (2009): A method for complex spatial delimitation of tourism destinations in South Transdanubia, Hungarian Geographical Bulletin 59(3) pp. 271-287.

AUBERT A. (2008): A desztináció lehatárolás problematikája a fejlesztési programok és a TDM-modell bevezetésének folyamatában. In:
Hanusz Á. (szerk.): A turizmus szerepe a kistérségek és a régiók gazdasági felzárkóztatásában. Nyíregyházi Fớiskola Turizmus és Földrajztudományi Intézet, Nyíregyháza. pp. 17-33.

AUBERT A. - SZABÓ G. (2007): Desztináció kutatás és földrajzi szemlélet. In: Aubert A. (szerk.): A térségi turizmuskutatás és tervezés módszerei és eredményei. PTE-TTK FI, Pécs. pp. 56-73.

AUBERT A. (2001): A turizmus és a területfejlesztés stratégiai kapcsolata Magyarországon. Turizmus Bulletin. 5. 1. pp. 44-49.

BIEGER, T. (2005): Management von Destinationen Lehr- und HandbücherzuTourismus, Verkehr und Freizeit,6.Auflage.OldenbourgWissenschaftsverlag, München-Wien.

BOUDVILLE, J. (1966): Problems of Regional Economic Planning. Edinburgh University Press, Edinburgh.

BRUGGES, E. A. (1981): Innovationsorientierte Regionalpolitik: Notizen zur einer neuen Strategie. Geografische Zeitschrift. 68. pp. 173-198.

GONDA T. - SPIEGLER P. (2012): A helyi szintú TDM szervezetek múködésének alapelvei és gyakorlata Orfú példáján. In: Hanusz Á. (szerk.): A turizmus területi dimenziói. Nyíregyházi Fóiskola, Nyíregyháza. pp 55-68.

HANUSZ Á. (2011): A helyi TDM szervezet megalakításának fontossága a Szatmár-beregi síkság területén. In: Frisnyák S. - Gál A. (szerk.): Kárpát-medence: Tájak, népek, tevékenységek: Földrajzi tanulmányok. Nyíregyházi Fóiskola Turizmus és Földrajztudományi Intézet; Bocskai István Gimnázium, Nyíregyháza; Szerencs. pp. 151-161.

HORVÁTH Z. - MAGYAR-PAPP J. - PÁLFI A. (2016): A turisztikai térhasználat és a desztináció menedzsment összefüggései. Modern Geográfia (IV.). pp. 1-14.

JÓNÁS-BERKIM. - CSAPÓ J. -PÁLFI A. - AUBERT A. (2015): A Market and Spatial Perspective of Health Tourism Destinations: The Hungarian Experience. International Journal of Tourism Research. 17. 6. pp. 602-612.

KÖBLI Á. (2015): Komplexitás és backcasting a fürdővárosok fejlesztésében. In: Hauck Zs. Keresztes É. R. - Poreisz V. - Tóbi I. (szerk.): Közgazdász Kutatók és Doktoranduszok II. Téli Konferenciája. Doktoranduszok Országos Szövetsége, Közgazdaságtudományi Osztály, Györ. pp. 27-38.

LENGYEL M. (2008): TDM múködési kézikönyv. Heller Farkas Fóiskola, Budapest.

LUFT, H. (2007): Destination Management in Theorie und Praxis - Organisation und Vermarktung von Tourismusorten 
und Tourismusregionen. Gmeiner Verlag. Messkirch.

MICHALKÓ G. (2012): Turizmológia. Akadémiai Kiadó Zrt., Budapest. pp. 110-123.

NTS 2005-2013 (2005): Nemzeti Turizmusfejlesztési Stratégia 2005-2013. Magyar Turisztikai Hivatal, Budapest.

NTS 2030 (2017): Nemzeti Turizmusfejlesztési Stratégia 2030. Magyar Turisztikai Ügynökség, Budapest.

PÁLFI A. (2017): A menedzsment szervezettel rendelkező turisztikai desztinációk jellemzői Magyarországon. PhD-értekezés. Pécsi Tudományegyetem, Pécs.

PÁLFI A. (2016): Turisztikai desztináció menedzsment szervezetek szerepe az innovációk elterjedésében Magyarországon. In: Ivancsóné Horváth Zs. - Darabos F. (szerk.): „Turizmus és innováció": VIII. nemzetközi turizmus konferencia 2016: tanulmányok. Széchenyi István Egyetem, Győr. pp. 40-50.

PÁLFI A. - NEMES V. - HORVÁTH Z. (2015): Tourismdestination management offices in the tourismregion of Balaton. Transylvanian Journal of Tourism and Territorial Development. 1. 1. pp. 70-77.

PÁLFI A. (2013): Turizmus menedzsment és irányítás Magyarországon - országos, regionális, térségi és helyi szintek szerepe a turizmusban. In.: Józsa K. - Nagy Gy. - Dudás R. (szerk.): Geográfus Doktoranduszok XIII. Országos konferenciája. CD-kiadvány. SZTE TTIK Gazdaság- és Társadalomföldrajzi Tanszék. Szeged.

PAPP ZS. M. (2013): Úton a versenyképes desztináció felé. PhD-értekezés. Pannon Egyetem, Veszprém.

RECHNITZER J. (1993): Szétszakadás vagy felzárkózás. A térszerkezetet alakító innovációk. MTA RKK, Győr.

RECHNITZER J. (1990): Az innováció-terjedés lehetőségei és feltételei. Területfejlesztés. 2. pp. 22-33.

SOMOSSY E. - LŐRINCZ K. (2014): A turisztikai desztináció menedzsment rendszer fejlesztése Magyarországon. In: Tózsa I. (szerk.): Turizmus és településmarketing tanulmánykötet. Budapesti Corvinus Egyetem, Budapest. pp. 27-36.

STEINECKE, A. (2013): Destinationsmanagement. UTB, Stuttgart.

SZABÓ G. (2006): Területi márkák Baranya és a Dél-Dunántúl turizmusában. In: Aubert A. (szerk.): Desztinációépítés és -menedzsment. Dél-dunántúli Turizmus Kiskönyvek, DDRIB, Pécs. pp. 60-91.

SZIVA I. (2010): Turisztikai desztinációk versenyképességének értelmezése és elemzése. PhD-értekezés. Budapesti Corvinus Egyetem, Budapest.
TŐZSÉR A. (2010): Versenyképes turisztikai desztináció: Új turisztikai versenyképesség modell kialakítása. Miskolci Egyetem, Miskolc.

ZEHRER, A. - PECHLANER, H. - HÖLZL, B. (2005): The Development of a Destination Management System (DMS) in South Tyrol. Anatolia: An International Journal of Tourism and Hospitality Research. 16. 2. pp. 147-161.

\section{Internetes források}

A Balatoni Turisztikai Desztináció Menedzsment Szervezetek támogatása: http://palyazat.gov. hu/doc/1567, Letöltve: 2017. szeptember 15.

Helyi és térségi turisztikai desztinációs menedzsment szervezetek és turisztikai klaszterek létrehozása és fejlesztése: http://palyazat.gov.hu/ doc/3637, Letöltve: 2017. szeptember 15.

NGM (2016): TDM szakmai regisztrációs lista: http://2010-2014.kormany.hu/download/e/92/41000/TDM\%20lista1104.pdf, Letöltve: 2017. szeptember 30.

GINOP-1.3.4-15 - Turisztikai szervezetek (TDM) fejlesztése: https://www.palyazat.gov.hu/ node/56703, Letöltve: 2017. szeptember 15.

DDOP-2008-2.1.3B - Desztináció menedzsment szervezetek kialakítása a régióban: http://palyazat. gov.hu/doc/1569, Letöltve: 2017. szeptember 15.

KSH (2016): Turizmus, vendéglátás. Területi Statisztika. www.ksh.hu

\section{Kormányhatározatok}

1092/2017. (II. 21.) Korm. határozat a Tokaj, Felső-Tisza és Nyírség kiemelt turisztikai fejlesztési térség meghatározásáról és a térségben megvalósítandó egyes fejlesztések megvalósításához szükséges források biztosításáról

1522/2017. (VIII. 14.) Korm. határozat a Debrecen, Hajdúszoboszló, Hortobágy és Tisza-tó kiemelt turisztikai fejlesztési térség meghatározásáról és a térségben megvalósítandó egyes beruházásokról

1550/2017. (VIII. 18.) Korm. határozat a Dunakanyar kiemelt turisztikai fejlesztési térség meghatározásáról, valamint a térségben megvalósítandó egyes fejlesztésekről

1861/2016. (XII. 27.) Korm. határozat a Balaton kiemelt turisztikai fejlesztési térség meghatározásáról és a térségben megvalósítandó egyes fejlesztések megvalósításához szükséges források biztosításáról

1862/2016. (XII. 27.) Korm. határozat a Sopron-Fertő kiemelt turisztikai fejlesztési térség meghatározásáról és a térségben megvalósítandó egyes fejlesztések megvalósításához szükséges források biztosításáról 